\title{
Soft-bottom macrofauna along the coast of Bahía de Los Ángeles, Gulf of California, during the summer and winter
}

\section{Macrofauna de fondo blando a lo largo de la costa de bahía de Los Ángeles, golfo de California, durante el verano y el invierno}

\author{
Luis Enrique Ángeles-González, Elena Solana-Arellano*, Victoria Díaz-Castañeda, \\ Olga Flores-Uzeta, Maricarmen Necoechea-Zamora
}

Departamento de Ecología Marina, Centro de Investigación Científica y de Educación Superior de Ensenada (CICESE), Carretera Ensenada-Tijuana, No. 3918, Zona Playitas, 22860 Ensenada, Baja California, Mexico.

* Corresponding author. E-mail: esolana@cicese.mx

\begin{abstract}
This work constitutes an effort to evaluate benthic biodiversity in Bahía de Los Ángeles, Gulf of California, Mexico. To characterize macrofauna at the family level, 2 sampling campaigns took place during summer 2013 and winter 2014 at 6 coastal stations. A total of 18,403 invertebrates were collected, 7,880 in summer and 10,523 in winter. These invertebrates were grouped into 6 phyla and 110 families, comprising 39 mollusks, 33 crustaceans, 30 polychaetes, 5 echinoderms, 2 cnidarians, and 1 cephalochordate. In both sampling periods, mollusks were the dominant group, especially in summer, followed by polychaetes and crustaceans, which were more abundant in winter. Ten new records were established for the area. The most abundant trophic groups were deposit feeders and carnivores. This research could be used to evaluate future changes in benthic assemblages in Bahía de Los Ángeles.
\end{abstract}

Key words: benthic diversity, seasonal variation, biosphere reserve, ecosystem engineers.

RESUMEN. Este trabajo constituye un esfuerzo para evaluar la biodiversidad bentónica en bahía de Los Ángeles, golfo de California, México. Para caracterizar la macrofauna a nivel de familia, se realizaron 2 campañas de muestreo durante el verano de 2013 y el invierno de 2014 en 6 estaciones costeras. Se recolectaron un total de 18,403 invertebrados, 7,880 en verano y 10,523 en invierno. Los invertebrados estuvieron representados por 6 filos y 110 familias, que estaban compuestas por 39 moluscos, 33 crustáceos, 30 poliquetos, 5 equinodermos, 2 cnidarios y 1 cefalocordado. En ambos periodos de muestreo, los moluscos fueron el grupo dominante, especialmente en verano, seguido de los poliquetos y los crustáceos, los cuales fueron más abundantes en invierno. Se establecieron 10 nuevos registros para el área. Los grupos tróficos más abundantes fueron organismos detritívoros y carnívoros. Esta investigación podría ser utilizada para evaluar cambios futuros en ensamblajes bentónicos en bahía de Los Ángeles.

Palabras clave: diversidad bentónica, variación estacional, reserva de la biosfera, ingenieros de ecosistemas.

\section{INTRODUCTION}

In Mexico, Bahía de Los Ángeles (BLA) is an important protected area for ecological conservation and tourism purposes in the state of Baja California, Mexico. Benthic studies in BLA began in the 1960s with the sampling campaigns of the Beaudette Foundation and the Scripps Institute of Oceanography (Barnard and Grady 1968). The collected samples were analyzed by Coan (1968), Reish (1968), Barnard (1969), and Donath-Hernández (1993). However, these studies were time-, site-, or taxonspecific and lacked statistical analyses. This study thus aimed to update the records and characterize general benthic coastal macrofauna in BLA at the family level. We also provide macrofaunal comparisons between 2 seasonal surveys. The results from this work could be useful for environmental assessment and conservation studies since benthic organisms respond quickly to disturbances (DíazCastañeda and Reish 2009).

\section{INTRODUCCIÓN}

En México, bahía de Los Ángeles (BLA) es un área protegida importante para la conservación ecológica y el turismo en el estado de Baja California, México. Los estudios bentónicos en BLA comenzaron en la década de 1960 con las campañas de muestreo de la Fundación Beaudette y el Instituto Scripps de Oceanografía (Barnard y Grady 1968). Las muestras recolectadas fueron analizadas por Coan (1968), Reish (1968), Barnard (1969) y Donath-Hernández (1993). Sin embargo, estos estudios fueron específicos para tiempos, sitios o grupos taxonómicos y carecieron de análisis estadísticos. Por lo tanto, este estudio tuvo como objetivo actualizar los registros y caracterizar la macrofauna bentónica costera general en BLA a nivel de familia. También proporcionamos comparaciones de macrofauna entre 2 muestreos estacionales. Los resultados obtenidos de este trabajo podrían ser útiles para la evaluación ambiental y los estudios de conservación, ya que los organismos bentónicos 


\section{MATERIALS AND METHODS}

Six coastal stations were sampled in BLA between 10 and $15 \mathrm{~m}$ depth in September 2013 (summer) and February 2014 (winter). Whenever possible, sampling stations were set equidistant to cover the entire coastal strip of the bay. At each station, 4 samples were collected using a Petite Ponar grab and sea surface temperature (SST) and salinity (SSS) measurements were made using a YSI model 2030 probe. Samples were sieved using a $1 \mathrm{~mm}$ mesh (Couto et al. 2010) and fixed in a $5 \%$ formaldehyde solution. Additional samples were taken to determine organic matter $(\mathrm{OM})$ content (Dean 1974).

In the laboratory, samples were washed using a $500 \mu \mathrm{m}$ mesh screen, and the macrofauna were preserved in $70 \%$ ethanol. Organisms were separated into major taxonomic groups (polychaetes, crustaceans, mollusks, echinoderms, and miscellaneous taxa), quantified, and identified at the family level. A redundancy analysis (RDA) was performed to analyze family composition and benthic groups and their relationships with environmental variables (SST, SSS, and $\mathrm{OM})$. Abundance data was treated with a Hellinger transformation (Legendre and Gallagher 2001). For the family composition analysis, only the most representative families were used ( $>20$ organisms). A similarity percentages analysis (SIMPER) was performed to further describe the contribution of families (\%) to the dissimilarity between seasons. All analyses were done in R 4.0.0 (R Core Team 2020) using the "vegan" library (Oksanen et al. 2019).

\section{RESULTS}

SST ranged from $\sim 29^{\circ} \mathrm{C}$ in summer to $\sim 15^{\circ} \mathrm{C}$ in winter. Conversely, SSS was lower in summer $(\sim 32)$ compared to winter $(\sim 34)$. We report OM concentrations between $1.00 \%-2.22 \%$ in summer and $1.28 \%-2.70 \%$ in winter (Table 1). A total of 18,403 invertebrates representing 6 phyla and 110 families were collected (7,880 in summer and 10,523 in winter). This work reports new family records for BLA: 2 Crustacea, 4 Mollusca, 1 Echinodermata, 1 Polychaeta, 1 Cnidaria, and 1 Chordata (Table S1). Six feeding guilds were reported: carnivores, herbivores, omnivores, filter feeders, deposit feeders, and scavengers, with carnivores being more abundant, followed by deposit and filter feeders. Mollusks dominated the coasts of BLA, mainly the carnivore Cylichnidae and the filter feeder Vermetidae. The Spionidae were abundant during summer and winter. The filter feeder Sabellidae, the deposit feeder Cirratulidae (polychaetes), and the burrowing Phoxocephalidae dominated in summer, while Corophiidae (detritivorous and omnivores) accounted for most of the crustacean abundance in winter.

Overall, mollusks were the dominant group in summer and winter, followed by polychaetes and crustaceans. Average densities per sampling date for most taxa were responden rápidamente a los disturbios (Díaz-Castañeda y Reish 2009).

\section{MATERIALES Y MÉTODOS}

Se muestrearon 6 estaciones costeras en BLA a 10-15 $\mathrm{m}$ de profundidad durante septiembre de 2013 (verano) y febrero de 2014 (invierno). Dentro de lo posible, las estaciones de muestreo fueron equidistantes para cubrir toda la franja costera de la bahía. En cada estación, se recolectaron 4 muestras con una draga Petite Ponar y se tomaron mediciones de la temperatura superficial del mar (TSM) y la salinidad (SSM) con una sonda YSI modelo 2030. Las muestras se tamizaron utilizando una malla de $1 \mathrm{~mm}$ (Couto et al. 2010) y se fijaron con una solución de formaldehído al 5\%. Se tomaron muestras adicionales para determinar el contenido de materia orgánica (MO) (Dean 1974).

En el laboratorio, las muestras se lavaron utilizando una malla de $500 \mu \mathrm{m}$ y la macrofauna se almacenó en etanol al $70 \%$. Los organismos se separaron en grupos taxonómicos (poliquetos, crustáceos, moluscos, equinodermos y taxones misceláneos), se cuantificaron y se identificaron a nivel de familia. Se realizó un análisis de redundancia (ARD) para analizar la composición de las familias y los grupos bentónicos y su relación con las variables ambientales (TSM, SSM y MO). La abundancia se transformó con una transformación de Hellinger (Legendre y Gallagher 2001). Para el análisis de la composición de las familias, solo se utilizaron las familias más representativas (>20 organismos). Se realizó un análisis de porcentaje de disimilitud (SIMPER) para describir con más detalle la contribución de las familias (\%) a la disimilitud entre las temporadas. Todos los análisis se realizaron en R 4.0.0 (R Core Team 2020) utilizando la biblioteca "vegan" (Oksanen et al. 2019).

\section{RESULTADOS}

La TSM varió de $\sim 29^{\circ} \mathrm{C}$ en verano a $\sim 5^{\circ} \mathrm{C}$ en invierno. Por el contrario, la SSM fue más baja en verano $(\sim 32)$ en comparación con el invierno $(\sim 34)$. Reportamos concentraciones de MO entre $1.00 \%-2.22 \%$ en verano y $1.28 \%-2.70 \%$ en invierno (Tabla 1). Se recolectaron un total de 18,403 invertebrados que representaron 6 filos y 110 familias $(7,880$ en verano y 10,523 en invierno). Este trabajo reporta nuevos registros de familias para BLA: 2 crustáceos, 4 moluscos, 1 equinodermo, 1 poliqueto, 1 cnidario y 1 cordado (Tabla S1). Se reportaron 6 gremios de alimentación: carnívoros, herbívoros, omnívoros, filtradores, detritívoros y carroñeros, siendo los carnívoros los más abundantes, seguidos por los detritívoros y los filtradores. Los moluscos predominaron en las costas de BLA, principalmente el carnívoro Cylichnidae y el filtrador Vermetidae. Durante el verano y el invierno, predominaron los carnívoros Spionidae. En el verano dominaron los filtradores Sabellidae, los detritívoros Cirratulidae (poliquetos) y los excavadores Phoxocephalidae, mientras 
Ángeles-González et al.: Gulf of California benthic macrofauna

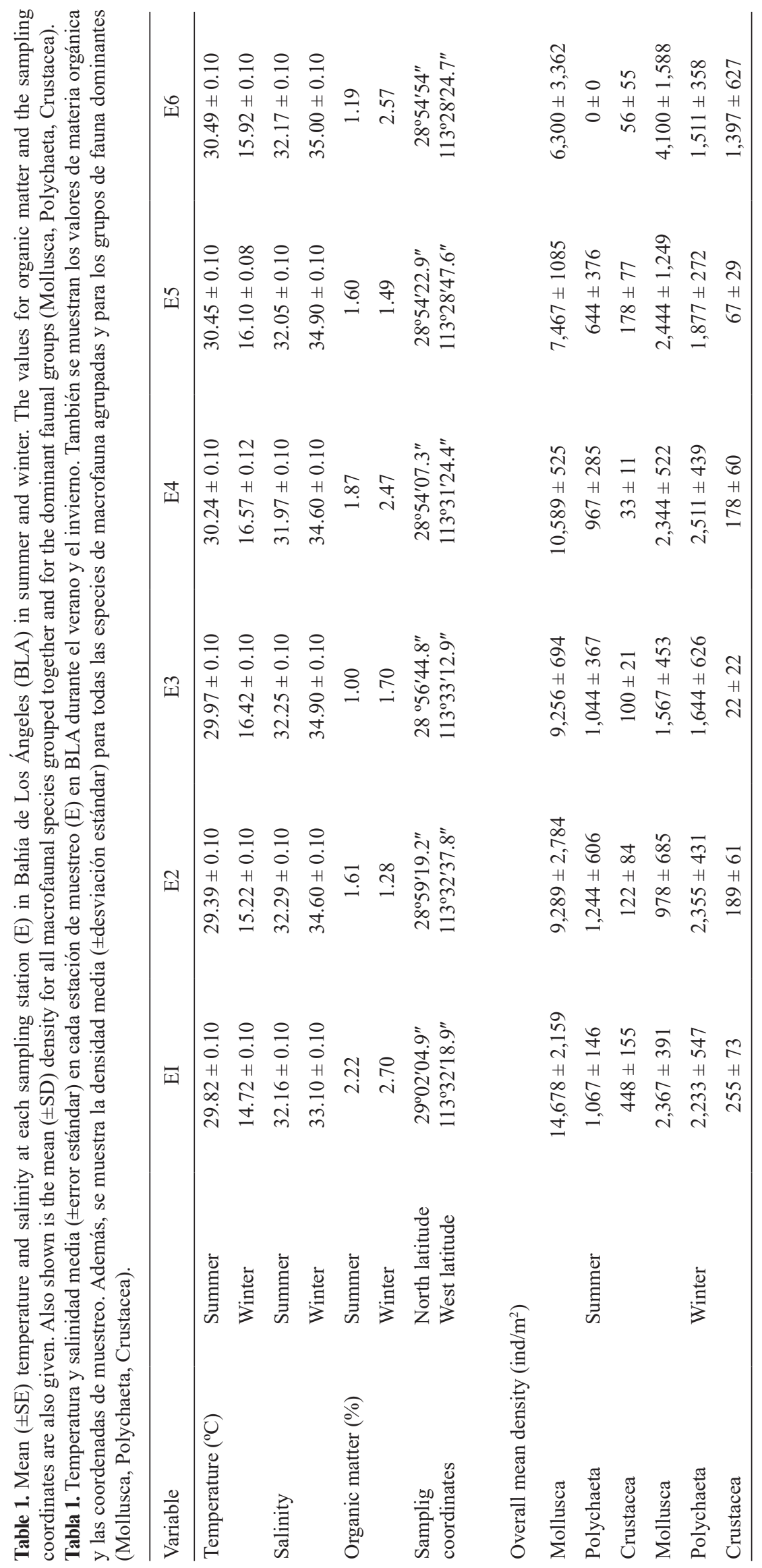


higher in winter than in summer, except for mollusks (Table 1). Many juvenile vermetids appeared brooding several capsules containing more than 300 embryos each. That is why small vermetid juvenile data were considered outliers and, therefore, omitted from statistical analysis. The RDA was significant $(P<0.05)$, showing that some families were associated with summer (i.e., Lascidae, Dentallidae, Collumbellidae) or winter (Sabellidae, Nereididae) conditions; however, other families, like Diadumenidae and Corophiidae, did not show such clear associations. Mollusks seemed to prefer summer conditions, while polychaetes thrived in winter. The relevance of $\mathrm{OM}$ was notably diminished by reducing the taxonomic resolution (Fig. 1). The summer and winter stations were separated because of the particular environmental conditions; however, station 6 was notably different. Finally, the SIMPER analysis showed that the families contributing about $50 \%$ of the differences observed between seasons were those belonging to the mollusks Cylinchnidae, Cerithiidae, Ovulidae, and Collumbellidae, and the Spionidae polychaetes (Table S2).

\section{Discussion}

Overall, deposit feeders, filter feeders, and carnivores predominated in summer. In contrast, carnivores and deposit feeders were more abundant in winter. We must emphasize that BLA is characterized by oceanographic processes that keep the water column mixed and favor primary productivity (Muñoz-Barbosa et al. 1991). These processes favor the development of deposit and filter feeders, which in turn are prey to carnivores and scavengers.

We also report the strong seasonality in SST and SSS in BLA. The trend has been noted for the Gulf of California (Brusca 1980) and BLA (Barnard and Grady 1968). The decrease in polychaete and crustacean fauna observed in the summer is consistent with the works of Coan (1968), Reish (1968), and Barnard (1969). Temperature has been hypothesized to possibly play an important role in determining the faunal composition of macrobenthic communities in BLA. Although no study has directly linked such association in this bay, increased macrofaunal polychaete and crustacean mortality in the Gulf of California is known to occur because of temperature seasonality (Brusca 1980). This study also provides the first description of gastropods in this region. Unlike polychaetes and crustaceans, mollusks, mainly gastropods, seem to have greater affinity for summer conditions. However, further studies are required to confirm this trend since no literature exists to contrast our results.

The RDA represent the first direct association between SST and SSS and macrobenthic fauna in BLA. Results suggest that SST and SSS may act synergistically on benthic populations. The influence of SST and SSS on faunal structure is not surprising since both control fitness at the organism, population, community, and ecosystem levels (Re et al. 2005, Angilletta 2009). Although OM seems to be an que Corophiidae (detritívoros y omnívoros) representó la mayor parte de la abundancia de crustáceos en el invierno.

En general, los moluscos fueron el grupo dominante en verano e invierno, seguidos de los poliquetos y los crustáceos. Las densidades promedio por fecha de muestreo para la mayoría de los taxones fueron más altas en invierno que en verano, excepto para los moluscos (Tabla 1). Muchos vermétidos juveniles se observaron incubando varias cápsulas que contenían más de 300 embriones cada una. Es por ello que los datos de vermétidos pequeños fueron considerados valores atípicos; por lo tanto, se omitieron del análisis estadístico. El análisis ARD fue significativo $(P<0.05)$ y mostró que algunas familias estaban asociadas con condiciones de verano (i.e., Lascidae, Dentallidae, Collumbellidae) o invierno (Sabellidae, Nereididae); sin embargo, otras familias, como Diadumenidae y Corophiidae, no presentaron asociaciones tan claras. Los moluscos parecieron preferir las condiciones de verano, mientras que los poliquetos prosperaron en invierno. También es notable que la importancia de la MO disminuyó al reducir la resolución taxonómica (Fig. 1). Las estaciones de verano e invierno estuvieron separadas por sus condiciones ambientales; sin embargo, la estación 6 fue notablemente diferente. Finalmente, el análisis SIMPER mostró que las familias que contribuyeron el $\sim 50 \%$ de las diferencias observadas entre estaciones fueron aquellas pertenecientes a los moluscos Cylinchnidae, Cerithiidae, Ovulidae y Collumbellidae, y a los poliquetos Spionidae (Tabla S2).

\section{Discusión}

En general, los detritívoros, los filtradores y los carnívoros predominaron en el verano. En contraste, los carnívoros y los detritívoros predominaron en el invierno. Debemos enfatizar que BLA se caracteriza por procesos oceanográficos que mantienen la columna de agua mezclada y favorecen la productividad primaria (Muñoz-Barbosa et al. 1991). Estos procesos favorecen el desarrollo de los detritívoros y los filtradores, que a su vez son presa de los carnívoros y los carroñeros.

Se observó una fuerte estacionalidad en la TSM y la SSM en BLA, una tendencia que se ha observado en el golfo de California (Brusca 1980) y en BLA (Barnard y Grady 1968). La disminución de la fauna de poliquetos y crustáceos observada en verano es consistente con los trabajos de Coan (1968), Reish (1968) y Barnard (1969). Se ha planteado la hipótesis de que la temperatura podría desempeñar un papel importante en la determinación de la composición de la fauna en las comunidades macrobentónicas en BLA. Aunque ningún estudio en la bahía vinculó directamente esta asociación, se sabe que la mortalidad de poliquetos y crustáceos macrofaunales aumenta en el golfo de California debido a la estacionalidad de la temperatura (Brusca 1980). Este estudio también describe por primera vez a los gasterópodos de esta región. A diferencia de los poliquetos y los crustáceos, los moluscos, principalmente gasterópodos, parecen tener una mayor afinidad por las condiciones de verano. Sin embargo, 
Ángeles-González et al.: Gulf of California benthic macrofauna
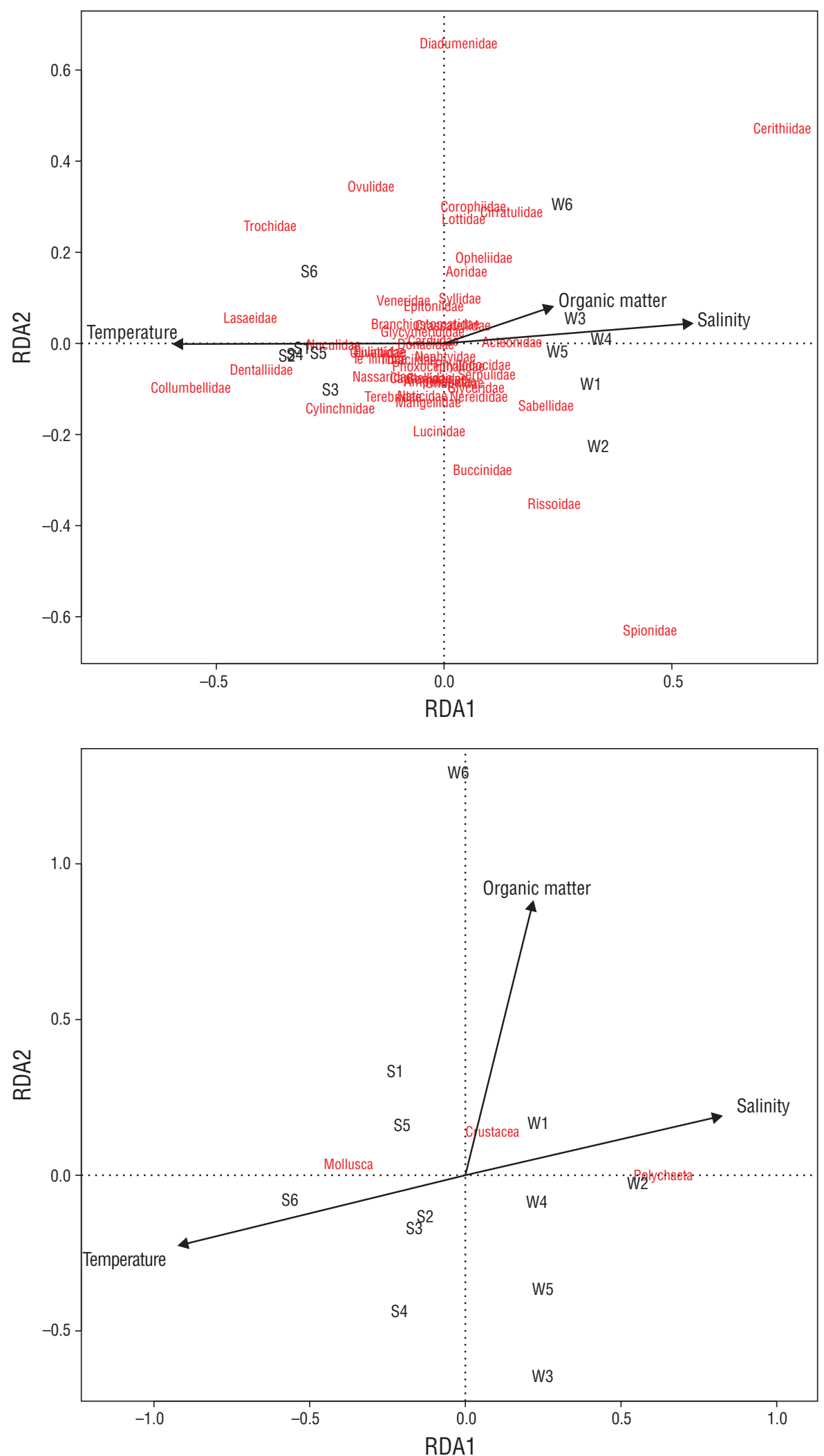

Figure 1. Redundancy analysis (RDA) triplots. Left: families, stations, and environmental variables. Right: orders, stations, and environmental variables. S, summer; $\mathrm{W}$, winter.

Figura 1. Graficas triespaciales del análisis de redundancia (RDA). Izquierda: familias, estaciones y variables ambientales. Derecha: órdenes, estaciones y variables ambientales. S, verano; $\mathrm{W}$, invierno. 
essential variable controlling faunal composition, the reduction of the resolution of the evaluated taxa weakens this association. The effect of $\mathrm{OM}$ is probably more evident when analyzed at the family level since different feeding families may be more strongly associated, directly or indirectly, with OM.

Regardless of these generalizations, the association of SST and SSS was weaker for crustaceans than for polychaetes, suggesting that other factors not considered here could be influencing faunal composition too. For example, in winter, the families Corophiidae (the most abundant family of crustacean) and Diadumenidae (anthozoan) were more abundant at station 6 , which was associated with macroalgae (Schmidt 1972, Appadoo et al. 2002). This pattern could be related to the vicinity of the La Mona estuary that flows into BLA and periodically provides OM. In fact, a small increase in OM was observed; however, further analysis is required to establish this trend. Regarding vermetids, the collected organisms seemed to correspond to a specific recruitment event (all organisms were small and of similar size) and were also associated with the presence of macroalgae.

In this study, the proximity of the sampling sites to the coast and the shallow depths may have influenced the diversity results. The characterization of BLA benthic assemblages will require covering the entire bay with a network of stations. The last evaluation of benthic organisms (cumaceans) was published by Donath-Hernández (1993) from samplings conducted by the Beaudette Foundation and the Scripps Institute of Oceanography, and the present study updates the knowledge of benthic biodiversity in this bay.

\section{ACKNOWLEDgMents}

This article is the result of a Master's degree thesis project carried out at CICESE with a Consejo Nacional de Ciencia y Tecnología (CONACYT, Mexico) scholarship to the first author. The Comisión Nacional de Áreas Naturales Protegidas (CONANP) granted the official permit (No. F00/DRPBCPN/RBBLACBS/164) to conduct research activities. No animal testing was performed during this study. The authors declare they do not have any conflict of interest.

\section{REFERENCES}

Angilletta MJ Jr. 2009. Thermal Adaptation a Theorical and Empirical Synthesis.New York: Oxford University Press. 302 p. https://doi.org/10.1093/acprof:oso/9780198570875.001.1

Appadoo C, Myers AA, Fagoonee I. 2002. The genus Mallacoota (Crustacea, Amphipoda, Melitidae) from Mauritius, with description of a new species. J Nat Hist. 36(7):767-796. https://doi.org/10.1080/00222930010024564

Barnard JL. 1969. A biological survey of Bahía de Los Angeles, Gulf of California, Mexico. IV. Benthic Amphipoda (Crustacea). San Diego Soc Nat Hist T. 15:175-228.

https://doi.org/10.5962/bhl.part.12057

Barnard JL, Grady JR. 1968. A biological survey of Bahia de Los Angeles, Gulf of California, Mexico. I. General account. San Diego Soc Nat Hist T. 15(6):51-66. se requieren más estudios para establecer esta tendencia, ya que no existe literatura para contrastar nuestros resultados.

Los ARD representan la primera asociación directa entre la TSM y la SSM y la fauna macrobentónica en BLA. Los resultados sugieren que la TSM y la SSM pueden actuar sinérgicamente en las poblaciones bentónicas. No es sorprendente que la TSM y la SSM influyan en la estructura de la fauna, ya que controlan la aptitud a nivel de organismo, población, comunidad y ecosistema (Re et al. 2005, Angilletta 2009). Aunque la MO parece ser una variable esencial que controla la composición de la fauna, la reducción de la resolución de los taxones evaluados debilita esta asociación. Por lo tanto, el efecto de la $\mathrm{MO}$ es probablemente más sustancial cuando se analiza a nivel de familia, ya que la alimentación de las diferentes familias puede estar asociada más fuertemente con la MO ya sea de manera directa o indirecta.

A pesar de estas generalizaciones, la asociación fue más débil para los crustáceos que para los poliquetos, lo que sugiere que otros factores no considerados aquí también podrían estar influyendo la composición de la fauna. Por ejemplo, en invierno, las familias Corophiidae (la familia más abundante de crustáceos) y Diadumenidae (antozoario) fueron más abundantes en la estación 6, que estaba asociada con macroalgas (Schmidt 1972, Appadoo et al. 2002). Este patrón podría estar relacionado con la cercanía del estuario La Mona, cuyas aguas fluyen hacia BLA y aportan MO periódicamente. En efecto, se observó un pequeño aumento de la MO; sin embargo, se requiere un análisis más detallado para establecer esta tendencia. En cuanto a los vermétidos, los organismos recolectados parecían corresponder a un evento de reclutamiento específico (todos los organismos eran pequeños y de tamaño similar) y también estaban asociados con la presencia de macroalgas.

En este estudio, la proximidad de los sitios de muestreo a la costa y su poca profundidad pudieron haber influido en los resultados de la diversidad. Se necesitaría cubrir toda la bahía con una red de estaciones para caracterizar las agrupaciones bentónicas en BLA. No obstante, la última evaluación de organismos bentónicos (cumáceos) fue publicada por Donath-Hernández (1993) con muestreos de la Fundación Beaudette y el Instituto Scripps de Oceanografía. Por lo tanto, el presente estudio actualiza el conocimiento de la biodiversidad bentónica de BLA.

\section{Agradecimientos}

Este artículo es el resultado de una tesis de maestría realizada en el CICESE con una beca del Consejo Nacional de Ciencia y Tecnología (CONACYT, México) otorgada al primer autor. La Comisión Nacional de Áreas Naturales Protegidas (CONANP) otorgó el permiso oficial (No. F00/DRPBCPN/ RBBLACBS/164) para realizar actividades de investigación. No se realizaron pruebas en animales durante este estudio. Los autores declaran que no tienen conflictos de intereses.

Traducido al español por Claudia Michel-Villalobos. 
Brusca RC. 1980. Common intertidal invertebrates of the Gulf of California. Tucson(AZ): University of Arizona Press. 513 p.

Coan EV. 1968. A biological survey of Bahía de los Ángeles, Gulf of California, México. III. Benthic Mollusca. San Diego Soc Nat Hist T. 15(8):107-132.

Couto T, Patrício J, Neto JM, Ceia FR, Franco J, Marques JC. 2010. The influence of mesh size in environmental quality assessment of estuarine macrobenthic communities. Ecol Indic. 10(6):1162-1173. https://doi.org/10.1016/j.ecolind.2010.03.019

Dean WE Jr. 1974. Determination of carbonate and organic matter in calcareous sediments and sedimentary rocks by loss on ignition: comparison with other methods. J Sediment Petrol. 44(1):242-248. https://doi.org/10.1306/74D729D2-2B21-11D7-8648000102C1865D

Díaz-Castañeda V, Reish DJ. 2009. Polychaetes in environmental studies. In: Shain D (ed.), Annelids as Model Systems in the Biological Sciences. New Jersey: John Wiley \& Blackwell. p. 205-227. https://doi.org/10.1002/9780470455203.ch11

Donath-Hernández FE. 1993. Cumaceos de Bahía de los Ángeles, Baja California, México (Crustacea, Peracarida) $=$ The Cumacea of Bahia de Los Ángeles, Baja California, México (Crustacea, Peracarida). Cienc Mar. 19(4):461-471. https://doi.org/10.7773/cm.v19i4.944

Legendre P, Gallagher ED. 2001. Ecologically meaningful transformations for ordination of species data. Oecologia.
129(2):271-280.

https://doi.org/10.1007/s004420100716

Muñoz-Barbosa A, Gaxiola-Castro G, Segovia-Zavala JA. 1991. Variabilidad temporal de la productividad primaria, clorofila y seston en la bahía de los Ángeles, golfo de California = Temporal variability of primary productivity, chlorophyll and seston in Bahia de Los Angeles, Gulf of California. Cienc Mar. 17(4):47-68.

http://dx.doi.org/10.7773/cm.v17i4.845

Oksanen J, Blanchet FG, Friendly M, Kindt R, Legendre P, McGlinn D, Minchin PR, O'Hara RB, Simpson GL, Solymos P, et al. 2019. Vegan: Community Ecology Package. R package version 2.5-6. [place unknown]: [publisher unknown]. https://CRAN.Rproject.org/package $=$ vegan

R Core Team. 2020. R: A Language and Environment for Statistical Computing. Vienna (Austria): R Foundation for Statistical Computing. https://www.R-project.org/

Re AD, Diaz F, Sierra E, Rodríguez J, Perez E. 2005. Effect of salinity and temperature on thermal tolerance of brown shrimp Farfantepenaeus aztecus (Ives) (Crustacea, Penaeidae). J Therm Biol. 30(8):618-622. https://doi.org/10.1016/j.jtherbio.2005.09.004

Reish DJ. 1968. A biological survey of Bahía de Los Angeles, Gulf of California, Mexico. II. Benthic polychaetous annelids. San Diego Soc Nat Hist T. 15(7):67-106.

Schmidt H. 1972. Prodomus zu einer Monographie der mediterranen Aktinien. Zoologica. 42:1-146.

Received 21 April 2020,

accepted 31 August 2020. 


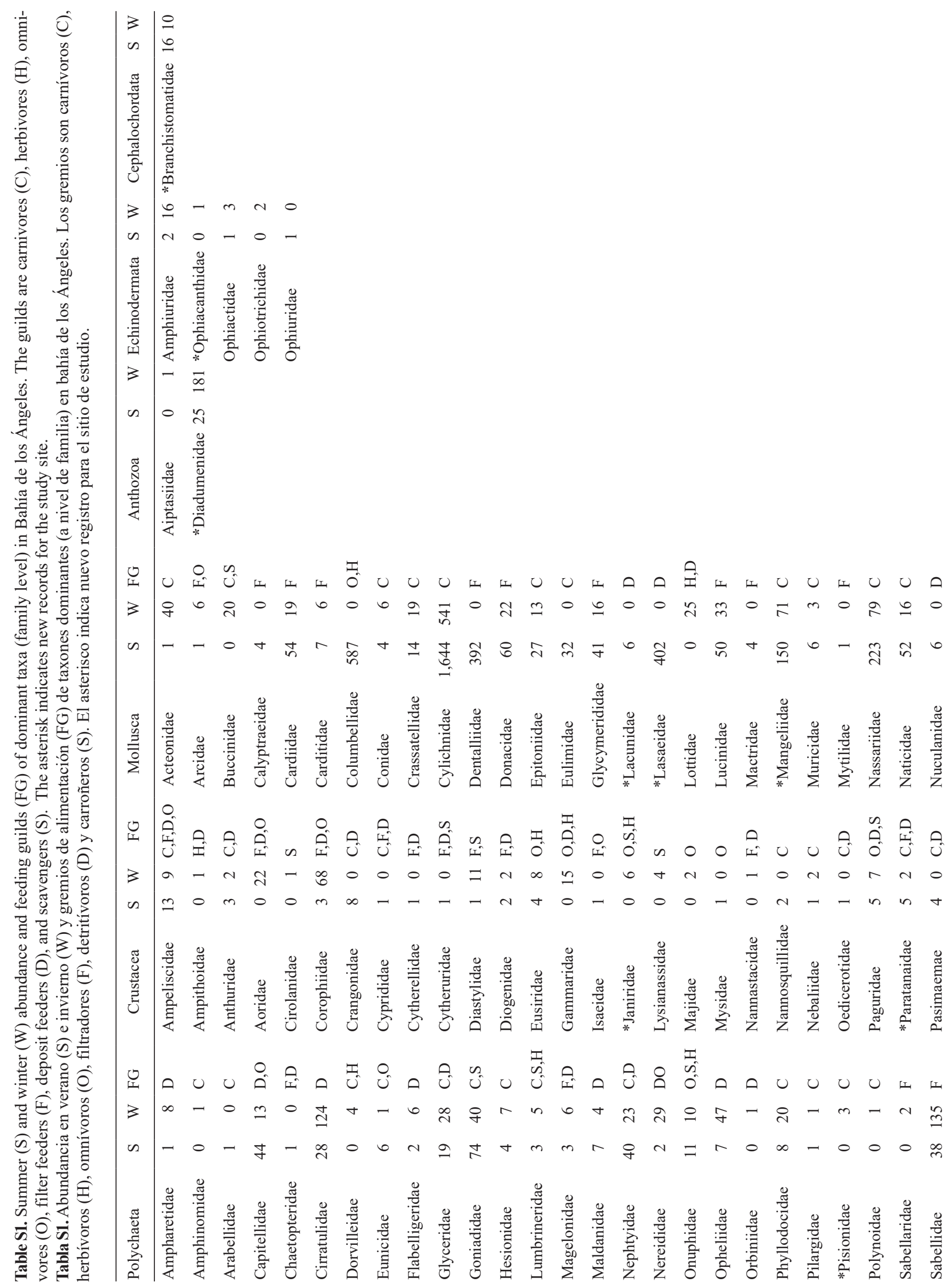




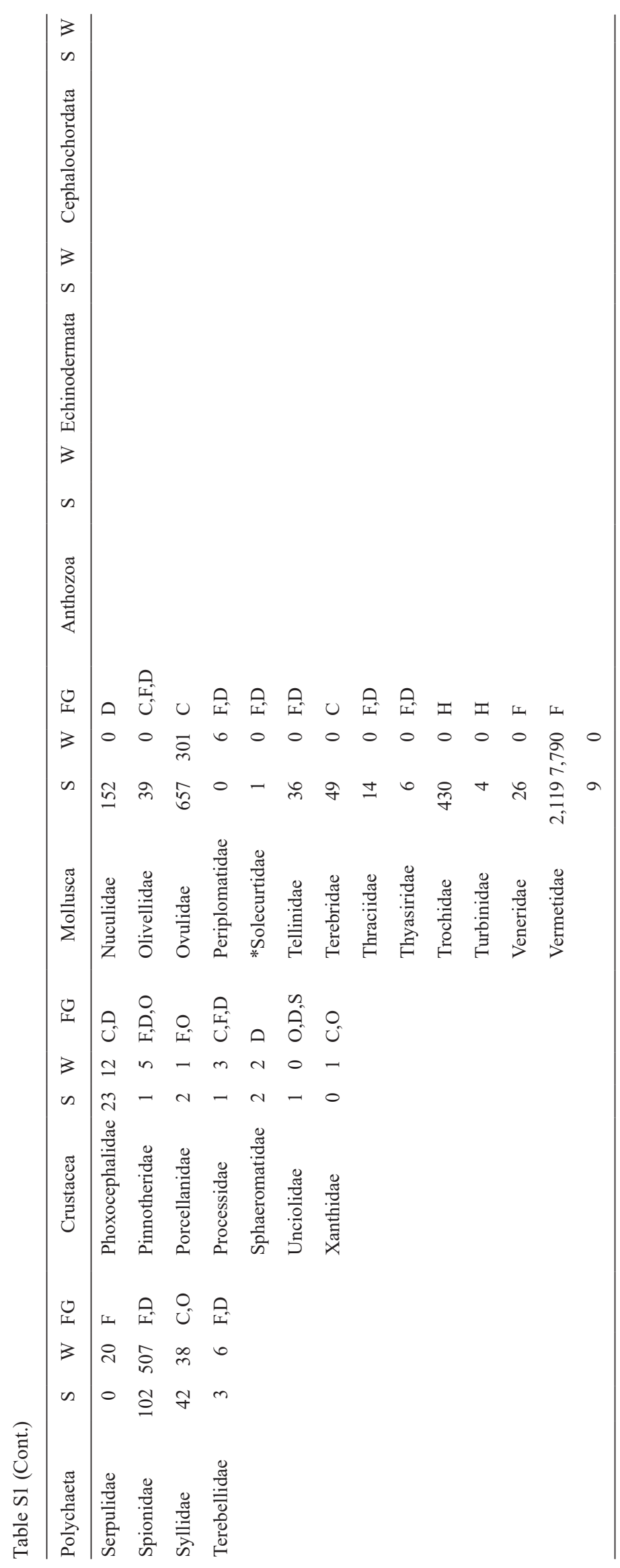




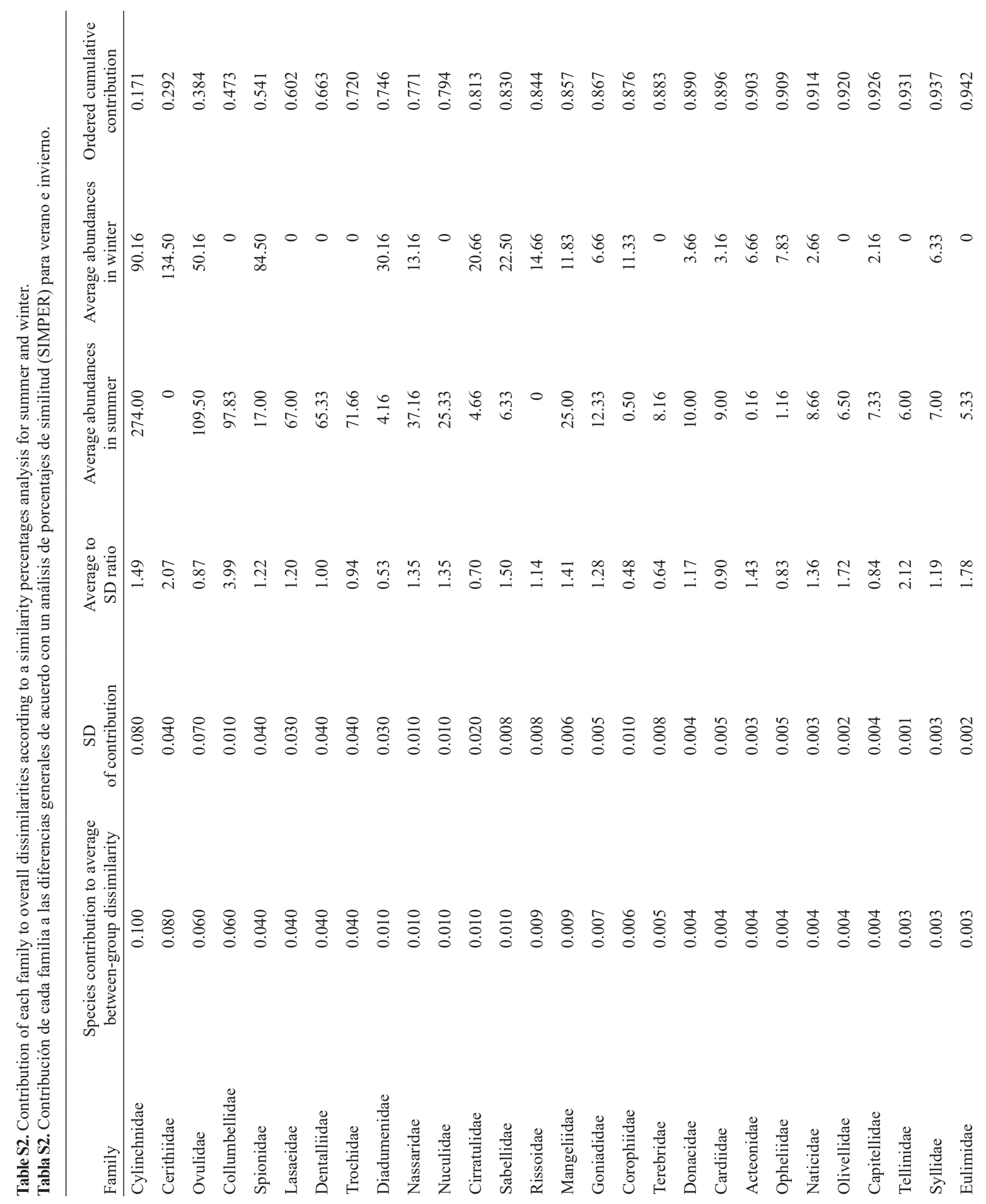




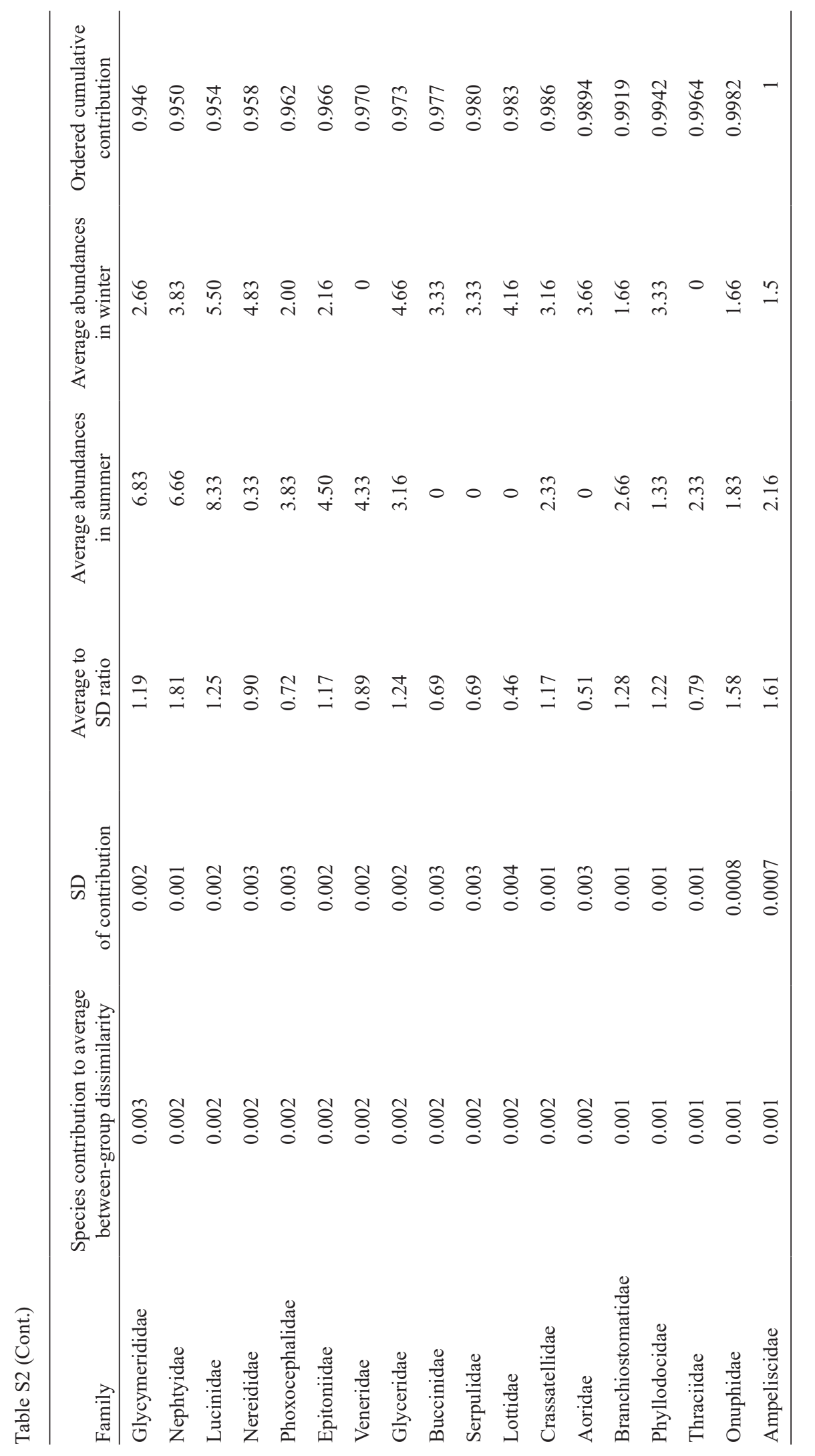

